\begin{tabular}{|c|c|}
\hline \multirow{3}{*}{ 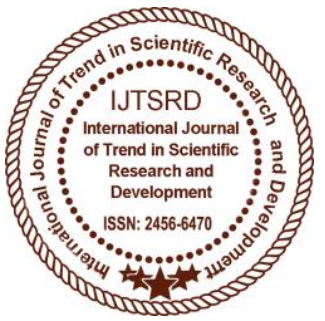 } & $\begin{array}{l}\text { International Journal of Trend in Scientific } \\
\text { Research and Development (IJTSRD) }\end{array}$ \\
\hline & International Open Access Journal \\
\hline & ISSN No: 2456 - 6470 | www.ijtsrd.com | Volume - 1 | Issue - 5 \\
\hline
\end{tabular}

\title{
Effectiveness of Planned Teaching Programme on Knowledge and Attitude on Prevention and Control of Dengue Fever to the Common People in the Community Set Up in Delhi
}

\author{
Rashmi Negi \\ Assistant Professor, Faculty of Nursing, \\ SGT University, Gurugram, Haryana
}

\author{
Shweta Handa \\ Assistant Professor, Faculty of Nursing, \\ SGT University, Gurugram, Haryana
}

\section{ABSTRACT}

An educational study was conducted to find out the effectiveness and attitude of community people regarding dengue fever. An estimated 500000 people with severe dengue require hospitalization each year, a large proportion of whom are children. About 2.5\% of those affected die. This study was done to assess the knowledge of community people on dengue fever, to administer a pamphlet on dengue fever and to evaluate the effectiveness of pamphlet on Dengue fever among the community People. Evaluative research approach and one group pre-test post test design was adopted to find out the effectiveness of health education on dengue fever among dengue fever. This study was conducted in community area of Village Madangir, New Delhi. The total sample comprises of 50 people. Purposive sampling technique was used to select the samples. Data was collected through structured questionnaire. Pamphlet was developed and distributed to enhance the knowledge of community people on dengue fever.

Data was analyzed and interpreted using descriptive statistics. Pre- test and post test knowledge score was 11.44 and 18.82 respectively. The mean difference for knowledge was7.38 and for attitude was 0.96.The standard deviation for knowledge pretest and posttest score were 2.04 and 0.95 and for attitude it was 1.26 and 0.83 respectively.

Keywords: Planned Teaching Programme, Dengue Fever, Knowledge and Attitude, Prevention and Control, Effectiveness

\section{INTRODUCTION}

"As I see it every day, you do one of the two things, build health or produce disease in yourself."

(Adele Davis)

Good health is a pre- requisite of human productivity and developmental process. Each individual has a right to a standard of living adequate in health of himself and his family as health is both a personal responsibility and a public concern. Life expectancy is increasing in most countries and greater number of people is at risk of developing communicable disease of various kinds. Among the communicable diseases, dengue fever is assuming increasing importance in population in developing countries. Nearly 4 million US citizens' lives in dengue endemic area, the most affected population resides in Puerto Rico. Dengue surveillance system were used to describe all suspected cases of dengue and the data suggest that the severity is working and persons 10-19 years of age and infants continued to be most affected ${ }^{1}$.

Half of the world's population lives in countries endemic for Dengue underscoring the urgency to find solution for dengue control. The consequences of simple dengue fever are loss of workdays for communities dependent on wages labour. The communities consequences of severe illness is high mortality rate, since tertiary level care required for dengue Hemorrhagic fever/ Dengue shock syndrome management is beyond the reach of the person at risk. (Department of public health and epidemiology, $2008)^{2}$. The incidence of dengue fever has increased 
International Journal of Trend in Scientific Research and Development (IJTSRD) ISSN: 2456-6470

dramatically around the world in recent decades. The actual numbers of total dengue cases are underreported and many cases are misclassified due to lack of health facilities in the community. When dengue first emerged in India during 50-60s it was reported mild but the disease profile has changed and more severity was reported during the year 1980s. One recent data published in an article indicates that 390 million dengue infections annually (95\% credible interval 284-528 million), of which 96 million (67136 million) manifest clinically (with any severity of disease). ${ }^{1}$ Another study, of the prevalence of dengue, estimates that 3.9 billion people, in 128 countries, are at risk of infection with dengue viruses which is really a matter of concern ${ }^{3}$.

Only nine countries had experienced severe dengue epidemics during and before 1970. The disease is now endemic in more than hundred countries in the WHO regions of Africa, the Americas, the Eastern Mediterranean, South-East Asia and the Western Pacific. The America, SouthEast Asia and Western Pacific regions are the most seriously affected. Dengue was also reported in Japan after a lapse of over 70 years. Since it is a mosquito borne disease and is therefore directly related to environmental sanitation, it can be prevented by appropriate sanitation. The year 2015 was characterized by large dengue outbreaks worldwide, with the Philippines reporting more than 169000 cases and Malaysia exceeding 111 000 suspected cases of dengue, representing a $59.5 \%$ and $16 \%$ increase in case numbers to the previous year, respectively. In Brazil over 1.5 million cases of dengue fever had been found in 2015, approximately 3 times higher than in 2014. Delhi, India, has been recorded its worst outbreak since 2006 with over 15000 plus cases. The dengue epidemic in India last year resulted in high mortality.

An estimated 500000 people with severe dengue require hospitalization each year, a large proportion of whom are children. About $2.5 \%$ of those affected die4.

\section{BACKGROUND OF THE STUDY}

New scientific insight into dengue vector ecology and disease transmission pattern together with more use of environmental management strategies may offer improved potential for combating dengue fever, the world's fastest growing vector borne disease. This disease urge is of particular since there is no curative treatment for dengue. In many settings spray application of insecticides or generalized community cleanup campaign of vector breeding sites had only a transient and limited effect. In 2002 the WHO general assembly confirmed dengue fever as a matter of international public health priority through a resolution to strengthen dengue control and research. (Dept. Public health and Epidemiology University, 2008). Seasonal variation in the incidence of dengue and large dengue outbreaks occurs every years.(University of Georgia, 2009) ${ }^{4}$. Dengue fever is one of the most important emerging diseases of the tropical and subtropical regions. Some 2.5-3 billion people lives in dengue endemic areas. It is estimated that each year 50 millions infections occurs with 500000 cases of DHF and at least 12000 deaths, mainly among children although fatalities could be twice as high. (Ministry of health and family welfare, $2008)^{5}$.

Dengue fever has been diagnosed in an increasing proportion of febrile travelers returning from tropics, ranging from $2 \%$ in the early 1990 's $16 \%$. The dengue virus spreads rapidly and the disease develops into the pandemic population. Most of the dengue virus infection in the travelers is acquired in Asia followed by America, with only a small proportion in Africa. (The New England Journal of Medicine, 2002) The annual average number of dengue fever/dengue haemorrhagic fever (DF/DHF) cases reported to the World Health Organization (WHO) has increased dramatically in recent years ${ }^{6}$.

Environmental management is generally considered to be an essential component of dengue prevention and control, particularly when targeting the most productive container habitats of the vector118. Source reduction, 'clean-up' campaigns, regular container emptying and cleaning (targeting not only households but also public spaces such as cemeteries, green areas and schools), installation of water supply systems, solid waste management and urban planning all fall under the rubric of environmental management. However, huge investments in infrastructure are needed to increase access to safe and reliable water supplies and solid waste disposal systems. In addition to overall health gains, such provision would clearly have a major impact on vector ecology, although the relationship is complex. For instance, cost recovery mechanisms, such as the introduction of metered water, might actually encourage the household collection and storage of roof catchment rainwater, 
International Journal of Trend in Scientific Research and Development (IJTSRD) ISSN: 2456-6470

which can be harvested at no cost. Although not studied carefully, the construction of community water distribution services to rural townships and villages might be contributing to the rural spread of dengue in Southeast Asia and elsewhere by facilitating domestic water storage. When decisions on such infrastructure development are being made, the views of Ministers of Public Health and municipal health departments are seldom voiced loudly, even when the economic and public health burden of diseases linked to water and sanitation are recognized, including those associated with dengue ${ }^{7}$.

\section{STATEMENT OF PROBLEM}

A study to evaluate the effectiveness of planned teaching programme on knowledge and attitude on prevention and control of dengue fever to the common people in the community set up in New Delhi

\section{OBJECTIVES OF THE STUDY}

1. To assess the knowledge of community people on dengue fever.

2. To administer a pamphlet on dengue fever.

3. To evaluate the effectiveness of pamphlet on Dengue fever among the community.

\section{OPERATIONAL DEFINITION:}

1. Effectiveness: Refers to the extent to which the exposure to planned teaching programme enables the community people to gain knowledge from pre test and post test as evident from knowledge score.

2. Attitude: Expression of feelings of community people towards prevention and control of dengue as evident from attitude scale.

Above Average: The attitude with score of $75 \%$ and above

Average: The attitude with score of $50 \%-75 \%$

Negative Attitude: The attitude with score of below $50 \%$

3. Knowledge: In this study knowledge is defined as the ability of people to respond to the items correctly on a structured knowledge questionnaire regarding prevention and control of dengue. The score has been an average and above average knowledge on the basis of response of the participants.

$\begin{array}{lc}\text { Knowledge } & \text { Score } \\ \text { Below Average } & <50 \% \\ \text { Average } & 50 \%-75 \% \\ \text { Above Average } & >75 \%\end{array}$

4. Planned Teaching Programme: It is systematically developed intervention and audio visual aids designed for a group of common people to provide information on prevention and control of dengue.

\section{CONCEPTUAL FRAMEWORK:}

The conceptual framework adopted for the study is based on Rosenstock's (1974) Health Belief Model. It provides a way of understanding and predicting how individuals will behave in relation to the health to comply with health education. The first component of this model involves the individual perception of susceptibility of risk factors of dengue fever. The second component is the individual's perception of the seriousness of the risk factors of dengue fever. This perception is influenced and modified by demographic characteristics such as (age, educational status, marital status, number of children, type of family) and socio-psychological variables such as social class of the individuals and perceived threat and illnesses and areas to action using flash card and pamphlets. The third components are the likelihood of action that will take preventive action resulting from the person's perceptions of the benefits of health education. The schematic representation of the conceptual framework is given below:- 


\section{CONCEPTUAL FRAMEWORK}

\section{CONCEPTUAL FRAMEWORK BASED ON ROSENSTOCK'S HEALTH BELIEF MODEL}

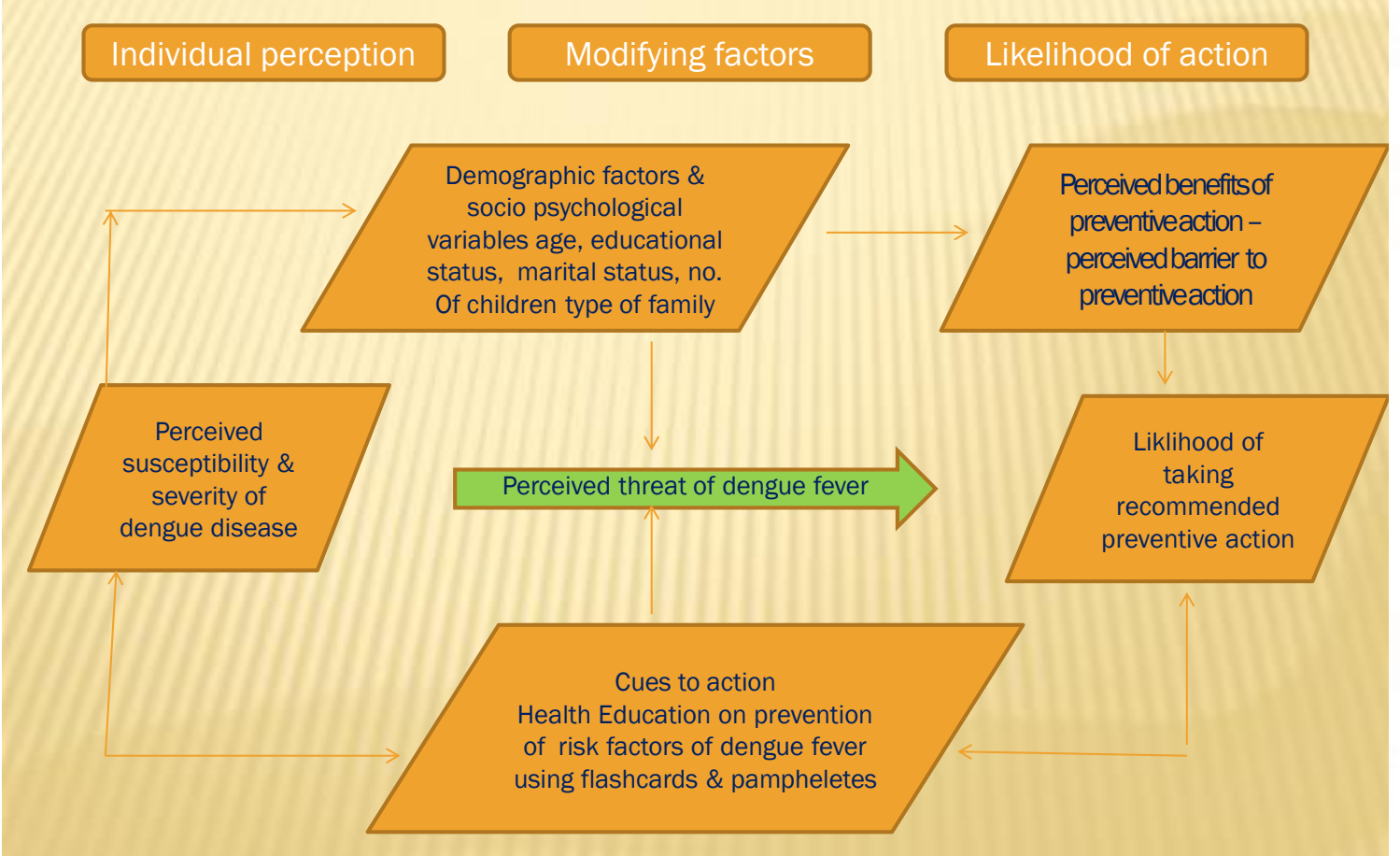

Figure1. Conceptual framework of the study based on Rosenstock's Health Belief Model

\section{MATERIALS AND METHODS:}

Research Approach: Quantitative research approach was used in the present study.

Research Designs: The design selected for the study was one group pre-test post design.

\section{RESEARCH DESIGN SHOWING ONEGROUP PRE-TEST POST-TEST DESIGN}


Figure2. Diagrammatic Representation of Research Design showing one group pre-test post-test design

Sample and sample size: The sample chosen for the present study were homemakers (women) and the sample size considered was 50 .

Sampling Techniques: Purposive sampling technique was used for the present study.

Description of Tool: The following tool was used for the data collection:

Section 1: This section consists of Demographic characteristics such as age, gender, marital status, type of family, religion, educational status, occupational status of husband, monthly income of family, health care facility preferred by the family, sources of maximum information regarding Dengue fever.

Section 2: This section consists of a knowledge questionnaire on Dengue Fever.

Section 3: This section consists of attitude of participants regarding prevention \& control of Dengue Fever.

Educational Module: The Educational Module was developed with the support of various literature and experts guidance. The module includes:-

$>$ Introduction and background about Dengue Fever

$>$ Transmission

$>$ Epidemiology

$>$ Types of Dengue Fever

$>$ Etiology

$>$ Signs and symptoms

$>$ Diagnostic Evaluation

$>$ Treatment

$>$ Prevention

Data collection: The Data was collected by prior permission from the concern authority. Oral consent from participants was obtained and data were collected by self administered questionnaire. The study was conducted in Madangir area in New Delhi for 5 days. Initially the researcher develops good rapport with the participants and they were assembled in a park, seated comfortably and questionnaire was distributed to the sample. Researcher clearly explained the questionnaire and distributed to the participants. The duration of education was $25 \mathrm{~min}$. Post test was done after 5 days.
Statistical Analysis: The collected data was conveniently summarized and tabulated by using descriptive statistics.

\section{RESULTS:}

The major findings of the study were as follows:

Section 1: Description of the sample characteristics:

The socio demographic data of sample were describes in terms of age, religion, marital status, type of family, number of children, education, occupation, monthly income and are presented in the forms of graphs and tables.

Table 1: Percentage distribution of participants by age $\mathbf{N}=\mathbf{5 0}$

\begin{tabular}{|l|l|l|} 
Age in years & $\begin{array}{l}\text { No. of } \\
\text { participants }\end{array}$ & $\begin{array}{l}\text { Percentage } \\
(\%)\end{array}$ \\
\hline $20-30$ & 17 & 34 \\
$31-40$ & 17 & 34 \\
$41-50$ & 11 & 22 \\
$51 \&$ above & 05 & 10 \\
\hline Total & 50 & 100 \\
\hline
\end{tabular}

Table 2: Percentage distribution of participants by educational status $\mathbf{N}=\mathbf{5 0}$

\begin{tabular}{|l|l|l|}
$\begin{array}{l}\text { Educational } \\
\text { Status }\end{array}$ & $\begin{array}{l}\text { No. } \\
\text { participants }\end{array}$ & $\begin{array}{l}\text { Percentage } \\
(\%)\end{array}$ \\
\hline Graduation & 01 & 02 \\
Higher & 08 & 16 \\
Secondary & 25 & 50 \\
High School & 16 & 32 \\
Illiterate & & \\
\hline Total & $\mathbf{5 0}$ & $\mathbf{1 0 0}$ \\
\hline
\end{tabular}

Table 3: Percentage distribution of participants by occupational status $\mathbf{N}=\mathbf{5 0}$

\begin{tabular}{|c|c|c|}
\hline $\begin{array}{l}\text { Occupational } \\
\text { Status }\end{array}$ & $\begin{array}{l}\text { No. of } \\
\text { participants }\end{array}$ & $\begin{array}{l}\text { Percentage } \\
(\%)\end{array}$ \\
\hline $\begin{array}{l}\text { Private } \\
\text { Business } \\
\text { Others }\end{array}$ & $\begin{array}{l}06 \\
10 \\
34\end{array}$ & $\begin{array}{l}12 \\
20 \\
64\end{array}$ \\
\hline Total & 50 & 100 \\
\hline
\end{tabular}


Table 4: Percentage distribution of participants by monthly income $\mathrm{N}=50$

\begin{tabular}{|l|l|l|}
$\begin{array}{l}\text { Monthly Income } \\
\text { (In Rs.) }\end{array}$ & $\begin{array}{l}\text { No. of } \\
\text { participants }\end{array}$ & $\begin{array}{l}\text { Percentage } \\
(\%)\end{array}$ \\
\hline $\mathbf{1 0 0 0 - 5 0 0 0}$ & 31 & 62 \\
$\mathbf{5 0 0 1 - 1 0 0 0 0}$ & 17 & 34 \\
$\mathbf{1 0 0 0 1}$ and above & 02 & 04 \\
\hline Total & 50 & 100 \\
\hline
\end{tabular}

Table 5: Percentage distribution of participants by marital status $\mathbf{N}=\mathbf{5 0}$

\begin{tabular}{|l|l|l|}
\hline Marital Status & $\begin{array}{l}\text { No. of } \\
\text { participants }\end{array}$ & $\begin{array}{l}\text { Percentage } \\
(\%)\end{array}$ \\
\hline Married & 44 & 88 \\
Unmarried & 06 & 12 \\
\hline Total & 50 & 100 \\
\hline
\end{tabular}

Table 6: Percentage distribution of participants by Number of Children $\mathbf{N}=50$

\begin{tabular}{|l|l|l|}
\hline Number of children & $\begin{array}{l}\text { No. of } \\
\text { participants }\end{array}$ & $\begin{array}{l}\text { Percentage } \\
(\%)\end{array}$ \\
\hline $\mathbf{0 1}$ & 06 & 12 \\
$\mathbf{0 2}$ & 11 & 22 \\
$\mathbf{0 3}$ & 11 & 22 \\
$\mathbf{0 4}$ & 17 & 34 \\
More & 05 & 10 \\
\hline Total & 50 & 100 \\
\hline
\end{tabular}

Table 7: Percentage distribution of participants by Type of family $\mathbf{N}=50$

\begin{tabular}{|l|l|l|}
\hline Type of family & $\begin{array}{l}\text { No. of } \\
\text { participants }\end{array}$ & $\begin{array}{l}\text { Percentage } \\
(\%)\end{array}$ \\
\hline Joint & 22 & 44 \\
Nuclear & 28 & 56 \\
\hline Total & 50 & 100 \\
\hline
\end{tabular}

The above data indicates that $34 \%$ of participants were between 20-30 years and 31-40 years of age group, $22 \%$ of participants belong to age group of 41 50 years \& of $10 \%$ of participants were in the age group of above 51 years. Majority of the participants (50\%) had high school education, 32\% were illiterate, $16 \%$ completed their higher secondary education and only $2 \%$ were graduates. Maximum percentage (68\%) were homemakers, 205 had some business and 12\% of participants working in private sector. Majority of the participants belongs to the income group of Rs. 1000-5000 and only participants had monthly income group of Rs.10001-15000. Maximum participants
$(88 \%)$ were married and $12 \%$ were unmarried. Out of total percentage $56 \%$ of participants were living in a nuclear family while $44 \%$ were in a joint family.

Section 2: Description of the knowledge score of prevention and control of Dengue Fever

Table7. Comparison of Knowledge score on prevention and control of Dengue fever before and after health education

\begin{tabular}{|l|l|l|l|}
\hline & Mean & $\begin{array}{l}\text { Standard } \\
\text { Deviation }\end{array}$ & $\begin{array}{l}\text { Mean } \\
\text { Difference }\end{array}$ \\
\hline Pretest & 11.44 & 2.04 & 7.38 \\
Posttest & 18.82 & 0.95 & \\
\hline
\end{tabular}

The data presented in the table 7 shows that the mean posttest score was higher than the mean pretest knowledge score. The mean pretest score was 11.44and increases to 18.82 during posttest with an average increase of 7.38

Section 3: Description of the Attitude score of prevention and control of Dengue Fever

Table 8.Comparison of Attitude score on prevention and control of Dengue fever before and after health education

\begin{tabular}{|c|c|c|c|}
\hline & Mean & $\begin{array}{l}\text { Standard } \\
\text { Deviation }\end{array}$ & $\begin{array}{l}\text { Mean } \\
\text { Difference }\end{array}$ \\
\hline $\begin{array}{l}\text { Pretest } \\
\text { Posttest }\end{array}$ & $\begin{array}{l}8.28 \\
9.26\end{array}$ & $\begin{array}{l}1.26 \\
0.83\end{array}$ & 0.96 \\
\hline
\end{tabular}

The data presented in the table 8 shows that the mean post test attitude score was higher than the mean pretest score. The mean pretest score was 8.28 which increase to 9.26 during posttest with an average increase of 0.96 .

\section{CONCLUSION:}

Dengue is now a global threat and is endemic or epidemic in almost every country located in the tropics. . Various methods to prevent and cure from the prevalent condition is required. While we wait for new tools such as vaccines, antiviral drugs and improved diagnostics, better use should be made of the interventions that are currently available. The challenge that awaits us in the near future will be how to scale up to deploy these new tools 6. Health department officials said that dengue cases peak when the virus that causes dengue - Flavivirus completes a cycle of three years. This is why higher number of cases was recorded in 2009, 2012 and 
again in the year 2015. Most of the cases were of patients in the age group of 14 to 45 years8. Doctors suggest using mosquito repellent, maintaining hygiene, keeping ones surroundings clean, wearing full-sleeved clothes and avoiding water accumulation anywhere around homes or workplaces as preventive measures. The larvae of aedes mosquito were found in coolers, planters and water tanks in homes. Dengue is emerging as a global threat and it is affecting tens of millions people annually and the need to bring it under control is very acute9. Dengue epidemics are frequent in India during the Monsoon which has no specific treatment and no vaccine is yet available 10 . On the basis of the findings of the above study conclusion can be made that community people still have deficient knowledge regarding dengue fever with a varying degree and health education was found to be effective in increasing knowledge regarding dengue fever. The pamphlets were found to be highly effective and acceptable by the people. Moreover provision of pamphlet has played a vital role in maintaining and reducing the effect of dengue fever in the community.

\section{IMPLICATION:}

The finding of the study had varied implications in different areas of nursing practice, nursing administration, nursing education and nursing research.

Nursing Education: Nursing is a profession which deals with people and their physical needs. Health does not specify to a single person but yield to the entire community. So a nurse while dealing with the public health can educate them about the Dengue fever. The Module can be used as reference material by the student nurses.

Nursing Practice: The study provided an insight into the inadequacy of knowledge of community people regarding dengue fever. Thus there is a need to emphasize on community teaching programme. So the community health nurse should be actively participating towards the development of health of the community as a whole. To sensitize people about the issues related to health education programme should be conducted in a variety of community settings in a large scale.

Nursing Administration: While planning nursing services at a large scale administration should focus on the epidemiological factors related to health conditions, social factors influencing the health issues, resources in terms of times, money, men and materials. So that the services that are planned and organized will be acceptable and accessible to all. Focus should be on facilitating the services and motivating each health personnel to provide cost effective services.

Nursing Research: Extensive and intensive researches are required to fight against dengue fever in the long run. As it an important issue related to health, we need to develop alternative method to deal with it. The nurse researcher should take up researches in various aspects of dengue fever and its prevention to generate more reliable data to give guidelines to the public for health education in various settings.

\section{RECOMMENDATIONS:}

1. A similar study can be done on a wider sample in different settings to generalize the findings.

2. A comparative study can be carried out to ascertain the knowledge and attitude about dengue fever among the community people in a community setting.

3. A descriptive study can be undertaken to assess the knowledge and attitude of the people in community area.

4. A similar study can be conducted to compare the effectiveness of planned teaching programme with that of pamphlet.

\section{REFERENCES:}

1) Chan.M.2012. Global strategy for dengue prevention and control, World Health Organisation. P.g- 1-8

2) World Health Organization. April 2017. Available from: URL: http://www.who.int/mediacentre/factsheets/fs117/ en/

3) Bhatt S, Gething PW, Brady OJ, Messina JP, Farlow AW, Moyes CL et.al. The global distribution and burden of dengue. Nature;496:504-507

4) Mariam Zameer. July 2013. Knowledge, attitudes and practices study of dengue viral infection and its association with environmental factors and health issues. Vol.7(7), P.P-711-717

5) Gupta N. Srivastava S. September 2012. Dengue in India. Indian J Med Res 136, September 2012 P.p-373-390.

6) Key.M.Tomasheh and AidshaRiveria. 2009.Description of large island-wide outbreak of 
International Journal of Trend in Scientific Research and Development (IJTSRD) ISSN: 2456-6470

dengue in Puerto Rico. The American Journal of Tropical Medicine and Hygiene.

7) Sinha S. 2016. Sinha S. 2016. Available from: URL:

http://www.hindustantimes.com/topic/denguedeaths.
8) Gupta N, Srivastava S, Jain A, Chaturvedi UC. Dengue in India. Indian $J$ Med Res. 2012;136(3):373-90. Review.

9) Park.K. Preventive \& social Medicine, Banarsidas Bhanot Publishers, Ed. 19, Pg. 651-57

10) Karen Saucier Lundy, Community health nursing, care of public health, Jones and Bartlett Publishers,368-72 